(c) American Dairy Science Association, 2007.

\title{
Effect of Protein-to-Fat Ratio of Milk on the Composition, Manufacturing Efficiency, and Yield of Cheddar Cheese
}

\author{
T. P. Guinee, ${ }^{1}$ E. O. Mulholland, J. Kelly, and D. J. O. Callaghan \\ Moorepark Food Research Centre, Teagasc, Moorepark, Fermoy, Co. Cork, Ireland
}

\begin{abstract}
Twenty-three Cheddar cheeses were prepared from milks with a protein content of $3.66 \%$ (wt/wt) and with different protein-to-fat ratio (PFR) in the range 0.70 to 1.15; the PFR of each milk differed by 0.02 . For statistical analysis, the 23 cheeses were divided into 3 PFR groups: low (LPFR; 0.70 to 0.85 ), medium (MPFR; 0.88 to 1.00 ) and high (HPFR; 1.01 to 1.15 ), which were compared using ANOVA. The numbers of PFR values in the LPFR, MPFR, and HPFR groups were 9, 7, and 7 , respectively. Data were also analyzed by linear regression analysis to establish potentially significant relationships among the PFR and response variables. Increasing PFR significantly increased the levels of cheese moisture, protein, $\mathrm{Ca}$, and $\mathrm{P}$, but significantly reduced the levels of moisture in nonfat substances, fat-in-DM, and salt-in-moisture. The percentage of milk fat recovered in the LPFR cheese was significantly lower than that in the MPFR or HPFR cheeses. In contrast, the recovery of water from milk to the LPFR cheese was significantly higher than that in the MPFR or HPFR cheeses. Increasing the PFR led to a significant decrease in the actual yield of cheese per $100 \mathrm{~kg}$ of milk but a significant increase occurred in the normalized yield of cheese per $100 \mathrm{~kg}$ of milk with reference values of fat plus protein (3.4 and 3.3\%, wt/wt, respectively). The results demonstrate that alteration of the PFR of cheese milk in the range 0.70 to 1.15 has marked effects on cheese composition, component recoveries, and cheese yield.
\end{abstract}

Key words: protein-to-fat ratio, milk, Cheddar cheese, composition

\section{INTRODUCTION}

Cheddar cheese manufacturers frequently ask if it is necessary to standardize cheese milk on a fat basis or on a protein-to-fat ratio basis, and how standardization affects manufacturing efficiency, cheese composition,

Received May 14, 2006.

Accepted August 21, 2006

${ }^{1}$ Corresponding author: tim.guinee@teagasc.ie and quality. Data from the Irish cheese industry between 2001 and 2003 indicate that the protein-to-fat ratio (PFR) of milk for manufacture of Cheddar cheese varied from $\sim 0.84$ to 1.02 , with protein varying from 2.99 to $3.59 \%$ (wt/wt) and fat from 3.26 to $4.2 \%$ (wt/ wt; Figure 1), changing with plant, time of year, and between years (Guinee et al., 2005). Unpublished data by the current authors, showing that the PFR of 6 leading mature, vintage brands of Cheddar cheeses available in Ireland and the United Kingdom varied from 0.68 to 0.85 , suggest that the PFR of the cheese milk varied from 0.81 to 1.02 , and that milk for Cheddar manufacture is generally not standardized to a defined PFR. Studies on Scottish creamery milks showed similar variation in PFR of cheese milk from $\sim 0.79$ to 0.97 (Banks et al., 1981; Banks and Tamime, 1987). Compared with the above, studies from the United States indicate much lower variation in the PFR of milks delivered to cheese plants in New York State (Barbano and Sherbon, 1984) and California (Bruhn and Franke, 1991). The variation in PFR of commercial milks is due to natural, seasonal-induced variations in levels and relative proportions of fat, protein, casein, and lactose (Banks et al., 1981; Banks and Tamime, 1987; Bruhn and Franke, 1991; O'Brien et al., 1999) as affected by stage of lactation, diet, husbandry practices, and region.

Differences in levels of fat, and hence PFR, that occur in milks used for the manufacture of low-fat and full-fat cheeses have marked influences on composition, yield, rheology, flavor, and sensory characteristics of cheese (Guinee and Law, 2002). Similarly, it has been demonstrated that variations in milk protein level at a given PFR, as affected by low concentration factor ultrafiltration of cheese milk, markedly affect these aspects of cheese (Mistry and Maubois, 2004; Guinee et al., 2006). An examination of the relationship between the composition and grading score has shown that the levels of fat-in-DM (FDM) and moisture in nonfat substances (MNFS), which are mainly determined by levels of moisture and protein, are major quality determinants of Cheddar cheese (Lawrence et al., 2004).

It is expected that variations in PFR of cheese milk, with a fixed protein level, would affect manufacturing efficiency, composition, and quality of Cheddar cheese. 


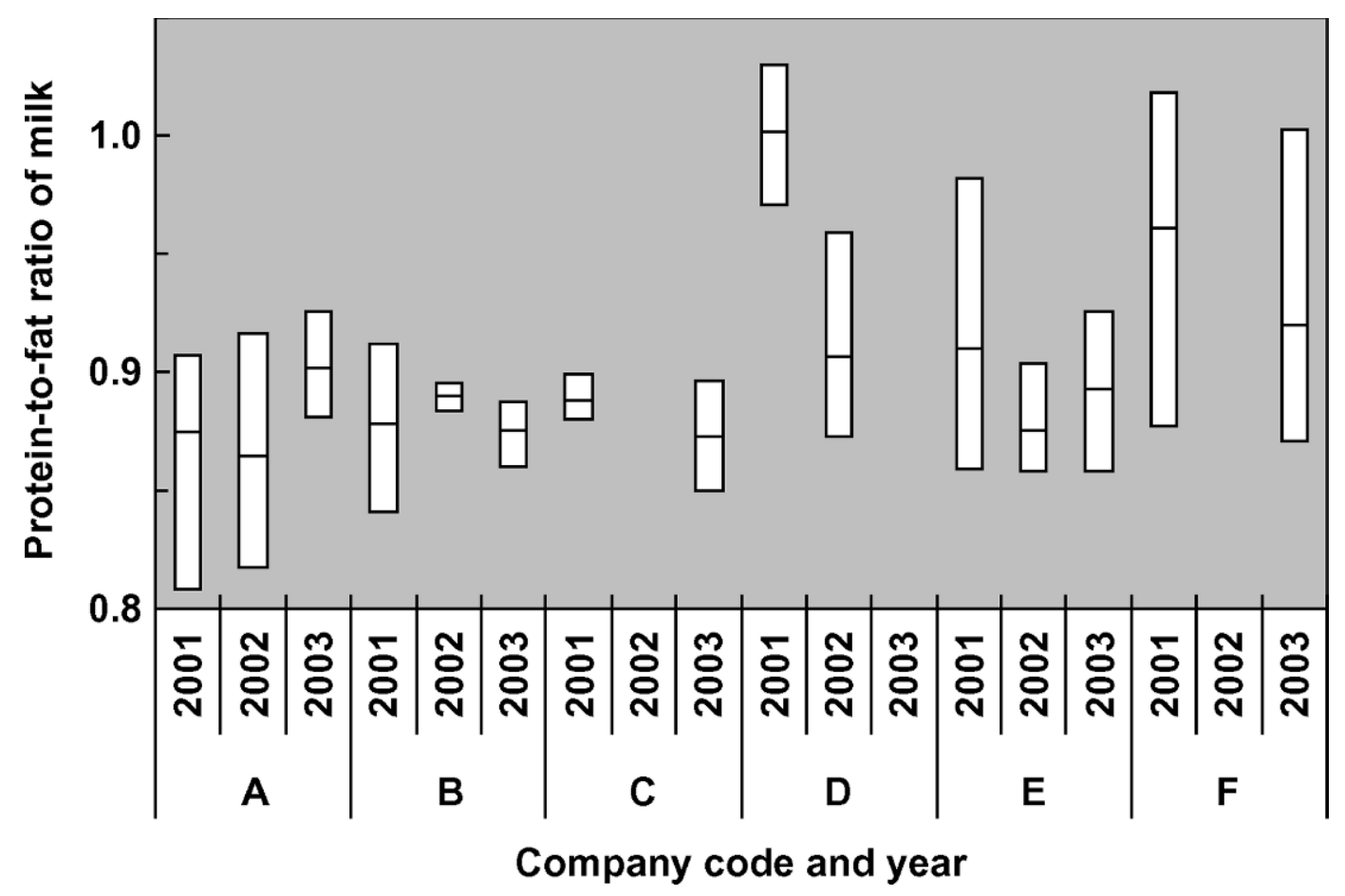

Figure 1. Protein-to-fat ratio of Irish factory (company A to F) cheese milks in years 2001 to 2003 . For each factory in any given year, the horizontal lines at the bottom, middle, and top of the bar represent the minimum, mean, and maximum values, respectively. Each factory was sampled at 3- to 4-wk intervals across the cheese-making season, which started in February and March and ended in September and October, depending on plant. Factories C, D, and F were not sampled in 2002, 2003, and 2002, respectively.

Yet, surprisingly, relatively little published information is available on the effect of PFR of milk on these aspects of Cheddar cheese; moreover, most of the available data relate to the effect of natural seasonal variation in PFR rather than to differences in PFR in which the milk protein level is within a small range (e.g., $\pm 0.1 \%$, wt/wt, of a mean value). Chapman and Burnett (1972) showed that large seasonal variations in PFR ( $\sim 0.72$ to 1.0 ) of herd milks over a 3 -yr period coincided with differences in MNFS, firmness, and grading scores for the body and texture of experimental Cheddar cheeses. Linear regression of the data of Chapman and Burnett (1972) indicates that the PFR of the milk was inversely correlated with the MNFS content and firmness of the cheese but was not related to cheese grade. Phelan (1981) reported no correlation between the PFR of milk (0.9 to 1.01) from Irish factories and the FDM content of the resultant Cheddar cheeses, and suggested that variations in fat loss to whey during manufacture may have had a greater effect on the FDM content than the PFR of the milk. Banks et al. (1981) reported that fat recovery in model Cheddar cheeses increased with PFR of the milk in the range of 0.75 to 1.10 , but the magnitude of the effect differed markedly among milks. In contrast, no clear relationship was found between the PFR of cheese milk and the recovery of fat or protein to Cheddar cheese in Scottish factories (Banks et al., 1981). The authors concluded that fat recovery to cheese as a function of PFR ratio was influenced by an unidentified compositional factor. In the above studies in which variation of PFR occurred as a result of natural variation over a season, rather than as an independent experimental variable, the varying effects of PFR on cheese efficiency and composition may have been confounded by other seasonal-related factors such as large variations in protein content or somatic cell count.

The objective of this study was to investigate the effect of altering the PFR, as an independent variable at a milk protein level of $3.69 \pm 0.09$, on the composition, yield, and manufacturing efficiency of Cheddar cheese. A range (0.70 to 1.15) of PFR values was chosen to span the variation found in Irish manufacturing milks, and to reflect the effects of more extreme values.

\section{MATERIALS AND METHODS}

\section{Preparation of Cheese Milks}

The experimental design consisted of 23 equally spaced target values of PFR in the range 0.70 to 1.15 for milks with a protein content of $3.69 \pm 0.09 \%$ (wt/ 
wt). The cheeses were made over a 3 -wk period in October 2004 in 6 cheese-making trials in each of which 4 milks (except for 3 in the final trial) were prepared with PFR values selected in a random order from the design. For each trial, raw milk ( $3.7 \% \mathrm{wt} / \mathrm{wt}$, protein) was obtained from a local dairy company and part of the milk was separated at $55^{\circ} \mathrm{C}$ to give skim and cream (48\% wt/wt fat). The treatment milks were then prepared by adding the desired quantities of cream or skim milk to the raw milk to give standardized milks with different PFR.

\section{Cheese Manufacture}

Standardized milks were stored overnight at $8^{\circ} \mathrm{C}$, pasteurized $\left(72^{\circ} \mathrm{C}, 15 \mathrm{~s}\right)$, and cooled to the renneting temperature of $31^{\circ} \mathrm{C}$. The pasteurized milk (455 kg) was inoculated at a rate of $1.5 \%$ (wt/wt) with a starter culture comprising Lactococcus lactis ssp. lactis strains 303 and 227 (Chr. Hansen Ireland Limited, Little Island, Co. Cork, Ireland), at a weight ratio of 1:1. The starters were grown separately overnight at $23^{\circ} \mathrm{C}$ in $10 \%$ (wt/vol) reconstituted, low heat skim milk powder heat-treated at $90^{\circ} \mathrm{C}$ for $30 \mathrm{~min}$ and blended just before addition to the milk. After 30 min, chymosin (Chymax Plus, Pfizer Inc., Milwaukee, WI), diluted 1:10 with distilled water, was added at a level of $19.4 \mathrm{~mL}$ of undiluted rennet per $100 \mathrm{~kg}$ of milk with $3.66 \%$ (wt/wt) protein. Cheddar cheeses were then made as described previously (Guinee et al., 2006), with the following parameters standardized during cheese manufacture both within and between trials: $\mathrm{pH}$ at different stages of manufacture (milk pH at rennet addition, 6.55; curd at whey drainage, 6.15; curd at salting, 5.25) and the firmness of the gel at cut (equivalent to a value of elastic shear modulus, $\mathrm{G}^{\prime}$, of $40 \mathrm{~Pa}$ ).

Following overnight pressing, cheeses were vacuumpackaged in Cryovac plastic bags (Cryovac Europe, St. Neots, Cambridgeshire, UK) and stored at $8^{\circ} \mathrm{C}$.

\section{Rennet Coagulation Properties}

A representative sample of vat milk was taken at 2 min after rennet addition and stirring, and its rennet gelation properties were measured at $31^{\circ} \mathrm{C}$ using dynamic low-amplitude strain oscillatory rheometry (Guinee et al., 2006). The elastic shear modulus, G', was used as an index of gel firmness. The following parameters were obtained from the $\mathrm{G}^{\prime}$-time curves: gelation time, defined as the time taken for $\mathrm{G}^{\prime}$ to reach a value of $\geq 0.2 \mathrm{~Pa}\left(\mathrm{GT}_{0.2 \mathrm{~Pa}}\right)$; maximum curd firming rate $\left(\mathbf{C F R}_{\text {max }}\right)$, the maximum slope of the $\mathrm{G}^{\prime}$-time curve; and set-to-cut time, the time to reach a $G^{\prime}$ value of 40 $\mathrm{Pa}\left(\mathbf{S C T}_{\mathbf{4 0}} \mathbf{P a}\right)$.

\section{Sampling and Mass Balance}

The pasteurized cheese milks were weighed to the nearest $0.1 \mathrm{~kg}$ into $500-\mathrm{L}$ cheese vats, as described previously (Guinee et al., 2006). Samples of well-agitated pasteurized cheese milk $\left(31^{\circ} \mathrm{C}\right)$ were taken from the vats before the addition of starter culture and later analyzed for composition.

Following cooking and stirring, the bulk whey (collected during whey drainage and curd cheddaring) and white whey (expressed during curd salting and pressing) were collected and sampled, as described by Guinee et al. (2006).

After mellowing, the salted curd was weighed (W1), molded, prepressed at $276 \mathrm{kPa}$ and reweighed (W2); the molded curd was again reweighed (W3) after overnight pressing at $552 \mathrm{kPa}$. The molds and cheesecloths were then removed and the final weight of the cheese (W4) was obtained for each treatment.

The white (salty) whey expressed from the curd during salting, mellowing, and prepressing was collected, weighed (W5), heated to $40^{\circ} \mathrm{C}$, and sampled representatively. The weight of white whey expressed during overnight pressing (W3 - W2) was added to W5 to determine the total weight of white whey.

\section{Analysis of Cheese Milks}

Cheese milk refers to the pasteurized milk with added starter culture; all other milks are supplied with the appropriate description (e.g., raw, standardized, or pasteurized). Raw and standardized milks were analyzed for fat, protein, and lactose content using a Milkoscan 203 (Foss Electric, Hillerød, Denmark). Pasteurized milks were analyzed for fat using the Röse-Gottlieb method (IDF, 1996), as well as for total N (IDF, 2001), casein and whey protein (IDF, 1964), and denatured whey protein (Fenelon and Guinee, 1999); lactose content was measured using the Milkoscan 203. The $\mathrm{pH}$ was measured using a Radiometer PHM $82 \mathrm{pH}$ meter fitted with a combination glass reference electrode (GK 2401C; Radiometer, Copenhagen, Denmark).

The levels of protein, casein, and fat of the cheese milk were calculated from the protein, casein, and fat contents of the pasteurized milk and starter, as described by Guinee et al. (2006).

\section{Analysis of Cheese Whey}

Whey was analyzed for fat by the Röse-Gottlieb method (IDF, 1987). Fines were measured using the Moorepark method, which involved centrifugation of a whey sample (typically $50 \mathrm{~mL}$ ) in a cylindrical tube with conical base at $1,100 \times g$ for $15 \mathrm{~min}$. After decantation of the supernatant, the fines pellet was washed with water 
onto a preweighed, dried Whatman GFF filter paper (Whatman International Ltd., Maidstone, UK) on a Buchner funnel; after filtration, the filter paper with wet fines was dried at $102^{\circ} \mathrm{C}$ for $2 \mathrm{~h}$ and the fines content was expressed in milligrams per kilogram of whey. The protein content of the whey was analyzed by determining the $\mathrm{N}$ content of the fines-free supernatant by Kjeldahl (IDF, 2001).

\section{Analysis of Cheese}

Grated cheeses were analyzed in triplicate at $14 \mathrm{~d}$ for protein (IDF, 2001), fat using the Röse-Gottlieb method (IDF, 1986), salt (IDF, 1988), and moisture (IDF, 1982). The $\mathrm{pH}$ was measured on cheese slurry prepared from $20 \mathrm{~g}$ of cheese and $12 \mathrm{~g}$ of deionized water (British Standards Institution, 1976). Cheese was ashed at $550^{\circ} \mathrm{C}$ according to the method of Kindstedt and Kosikowski (1985), and the ash was analyzed for Ca (IDF, 1992) and $\mathrm{P}$ (IDF, 1990).

\section{Measuring Component Losses and Recoveries and Cheese Yields}

The percentage milk fat lost in whey streams (e.g., bulk whey) and fat recovered to cheese were calculated on the basis of fat levels in cheese milk, wheys, and cheese as described by Guinee et al. (2006). The percentages of loss and recovery of milk protein were similarly calculated.

The recovery of water from milk to cheese (WRC, in $\mathrm{kg}$ of moisture in cheese per $100 \mathrm{~kg}$ of milk) was calculated as the product of actual cheese yield and the weight fraction of moisture in the cheese.

The actual cheese yield $\left(\mathbf{Y}_{\mathbf{A}}\right)$, as measured from the weights of cheese milk and pressed cheese, is expressed as kilograms per $100 \mathrm{~kg}$ of cheese milk. Because of differences in the PFR of the cheese milk, the composition of the cheese milks and resultant cheeses differed, as discussed later. To eliminate the effects of differences in milk composition to yield and, hence, enable yields of cheese from milks of different composition to be compared, cheese yield was also expressed as normalized yield ( $\left.\mathbf{Y}_{\text {AFPRM }}\right)$; that is, yield per $100 \mathrm{~kg}$ of milk normalized to reference values of fat plus protein (3.4 and 3.3\% wt/wt, respectively), as defined by Guinee et al. (2006).

Yield was also expressed as moisture-adjusted (to $38.5 \% \mathrm{wt} / \mathrm{wt})$ cheese yield $(\mathrm{kg} / 100 \mathrm{~kg}$ of cheese milk; $\left.\mathbf{Y}_{\mathbf{M A}}\right)$, and as normalized moisture-adjusted yield (Y $\mathbf{Y}_{\text {MARFPM }}$ ), expressed as kilograms of cheese with $37.5 \%$ $(\mathrm{wt} / \mathrm{wt}$ ) moisture per $100 \mathrm{~kg}$ of milk normalized to reference values of fat plus protein $(3.4$ and $3.3 \% \mathrm{wt} / \mathrm{wt}$, respectively), as defined by Guinee et al. (2006). The latter expression allows the direct effect of PFR on cheese yield to be determined without the interfering effect of differences in the levels of milk fat and cheese moisture.

\section{Statistical Analysis}

The range of investigated PFR values was divided into 3 groups to facilitate statistical analysis, namely, low (LPFR; 0.70 to 0.85 ), medium (MPFR; 0.88 to 1.00 ) and high (HPFR; 1.01 to 1.15). The compositional data for the 3 treatments were compared using one-way ANOVA using the GLM procedure of SAS (SAS Institute, 1995). Duncan's multiple-comparison test was used as a guide for pair comparisons of the treatment means. The level of significance was determined at $P<0.05$.

The data were also analyzed for correlations among the PFR of the cheese milk and the response variables (e.g., cheese yield, cheese moisture). The significance of correlations were determined by applying Student's $t$ test to $\mathrm{r}^{2}$ with $n-2 \mathrm{df}$, where $n$ is the actual number of data points, and df is the degrees of freedom.

\section{RESULTS AND DISCUSSION}

\section{Milk Composition}

Reducing the PFR coincided with a significant increase in the fat content but did not otherwise influence milk composition significantly (Table 1 ). The composition of milk, apart from fat content, was typical of Irish milk from spring-calved herds in October when the content of protein and casein are high (Mehra et al., 1999; O'Brien et al., 1999). The level of denatured whey protein $(5.8 \pm 1.86 \% \mathrm{wt} / \mathrm{wt})$ is similar to that reported previously for similar pasteurization conditions (Lau et al., 1990; Guinee et al., 2006).

\section{Rennet Coagulation Properties and Cheese-Making Characteristics}

The PFR did not significantly affect the rennet gelation or curd-forming properties of the milk as reflected by the absence of significant differences among the mean values of $\mathrm{GT}_{0.2 \mathrm{~Pa}}, \mathrm{CFR}_{\max }$, and $\mathrm{SCT}_{40 \mathrm{~Pa}}$ for the LPFR, MPFR, and HPFR milks (Table 2). Likewise, the absence of significant differences among the times between starter addition and maximum scald (time to reach the cook temperature, $39^{\circ} \mathrm{C}$ ), whey drainage, and curd milling show that PFR of cheese milk had no effect on rate of acid production during cheese manufacture. These results are consistent with the similar levels of protein in all milks and the standardization of set $\mathrm{pH}$. 
Table 1. Composition of pasteurized milks with different protein-to-fat ratio (PFR)

\begin{tabular}{|c|c|c|c|c|}
\hline \multirow[b]{2}{*}{ Composition } & \multicolumn{3}{|c|}{ Treatment code ${ }^{1}$} & \multirow[b]{2}{*}{$\mathrm{SED}^{2}$} \\
\hline & LPFR & MPFR & HPFR & \\
\hline PFR & $0.78^{\mathrm{c}}$ & $0.94^{\mathrm{b}}$ & $1.07^{\mathrm{a}}$ & 0.0026 \\
\hline Casein-to-fat ratio & $0.60^{\mathrm{c}}$ & $0.71^{\mathrm{b}}$ & $0.80^{\mathrm{a}}$ & 0.019 \\
\hline Protein $(\%, w t / w t)$ & $3.66^{\mathrm{a}}$ & $3.66^{\mathrm{a}}$ & $3.65^{\mathrm{a}}$ & 0.056 \\
\hline Casein number ${ }^{3}$ & $76.9^{\mathrm{a}}$ & $76.44^{\mathrm{a}}$ & $77.08^{\mathrm{a}}$ & 0.359 \\
\hline Casein $(\%, w t / w t)$ & $2.81^{\mathrm{a}}$ & $2.81^{\mathrm{a}}$ & $2.80^{\mathrm{a}}$ & 0.048 \\
\hline Fat $(\%$, wt/wt $)$ & $4.71^{\mathrm{a}}$ & $3.91^{\mathrm{b}}$ & $3.41^{\mathrm{c}}$ & 0.143 \\
\hline Lactose $(\%$, wt/wt) & $4.40^{\mathrm{a}}$ & $4.44^{\mathrm{a}}$ & $4.41^{\mathrm{a}}$ & 0.052 \\
\hline NPN (\% of total N) & $5.56^{\mathrm{a}}$ & $6.30^{\mathrm{a}}$ & $5.56^{\mathrm{a}}$ & 0.393 \\
\hline Whey protein (\% of total protein) & $17.60^{\mathrm{a}}$ & $17.26^{\mathrm{a}}$ & $17.40^{\mathrm{a}}$ & 0.526 \\
\hline Denatured whey protein (\% of total whey protein) & $5.60^{\mathrm{a}}$ & $4.79^{\mathrm{a}}$ & $6.03^{\mathrm{a}}$ & 0.965 \\
\hline
\end{tabular}

\section{Cheese Composition}

Increasing the PFR had marked effects on cheese composition (Table 3). Most notable were the significant increases in contents of moisture and protein $(0.6$ and $1.12 \% \mathrm{wt} / \mathrm{wt}$ per $0.1 \mathrm{PFR}$, respectively) and reductions in levels of FDM and MNFS (1.9 and 0.7\% wt/wt per 0.1 PFR, respectively; Figure 2a). In agreement with the trend noted for MNFS, the increase in PFR was paralleled by a significant decrease in moisture in cheese obtained from $100 \mathrm{~kg}$ of milk (Figure 2b), indicating a concomitant decrease in the WRC. These results, which concur with those of Fenelon and Guinee (1999) for cheeses ranging in fat content from 7 to $31 \%$ (wt/ wt), reflect a decrease in the level of syneresis from the curd matrix during manufacture and an increase in the water-to-protein ratio of the finished cheese as the fat content of the milk was increased, or as PFR decreased. This is scarcely surprising as the greater the number of fat globules within the matrix (Dejmek and Walstra, 2004), the lower is the expected percolation rate of whey through the matrix; occluded fat globules may be considered as "stoppers" that clog the pores of the paracasein matrix and thereby impede the outward flux of whey from the curd particles. However, the decreases in MNFS and WRC as the PFR was increased may be offset to varying degrees by intervention in the cheese manufacturing process; for example, elevation of pasteurization temperature, preacidification of cheese milk before rennet addition, use of selected strains of ropy exopolysaccharide-producing starter cultures, alteration of cooking rate and scald temperature, $\mathrm{pH}$ of curd at whey drainage, and curd-handling operations. The

Table 2. Effect of increasing protein-to-fat ratio (PFR) of cheese milk on the rennet coagulation and curdforming characteristics during Cheddar cheese manufacture

\begin{tabular}{lcccc}
\hline & \multicolumn{3}{c}{ Treatment code $^{2}$} \\
\cline { 2 - 4 } Characteristic $^{1}$ & LPFR & MPFR & HPFR & SED $^{3}$ \\
\hline $\mathrm{GT}_{0.2 \mathrm{~Pa}}(\min )$ & $11.28^{\mathrm{a}}$ & $15.02^{\mathrm{a}}$ & $16.07^{\mathrm{a}}$ & 2.49 \\
$\mathrm{SCT}_{40 \mathrm{~Pa}}(\mathrm{~min})$ & $35.61^{\mathrm{a}}$ & $38.16^{\mathrm{a}}$ & $37.23^{\mathrm{a}}$ & 1.65 \\
$\mathrm{CFR}_{\max }(\mathrm{Pa} / \mathrm{min})$ & $3.13^{\mathrm{a}}$ & $2.78^{\mathrm{a}}$ & $2.98^{\mathrm{a}}$ & 0.20 \\
Starter addition-to-max scald (min) & $126^{\mathrm{a}}$ & $129^{\mathrm{a}}$ & $125^{\mathrm{a}}$ & 2.54 \\
Starter addition-to-drain (min) & $181^{\mathrm{a}}$ & $181^{\mathrm{a}}$ & $187^{\mathrm{a}}$ & 2.95 \\
Starter addition-to-mill (min) & $298^{\mathrm{a}}$ & $298^{\mathrm{a}}$ & $304^{\mathrm{a}}$ & 4.85 \\
\hline
\end{tabular}

${ }^{a}$ Values within a row sharing a common superscript are not significantly different at $P<0.05$.

${ }^{1} \mathrm{GT}_{0.2 \mathrm{~Pa}}=$ Gelation time defined as the time taken for elastic shear modulus, $\mathrm{G}^{\prime}$, to reach a value of $\geq 0.2$ $\mathrm{Pa} ; \mathrm{SCT}_{40 \mathrm{~Pa}}=$ set-to-cut time, defined as the time to reach a $\mathrm{G}^{\prime}$ value of $40 \mathrm{~Pa} ; \mathrm{CFR}_{\max }=$ maximum curd firming rate, defined as the maximum slope of the $\mathrm{G}^{\prime}$-time curve.

${ }^{2}$ Twenty-three milks with PFR in the range 0.70 to 1.15 were grouped based on PFR as low (LPFR: 0.70 to 0.85 ), medium (MPFR: 0.88 to 1.00), or high (HPFR: 1.01 to 1.15); the number of samples in LPFR, MPFR, and HPFR was 9, 7, and 7, respectively.

${ }^{3} \mathrm{SED}=$ Standard error of difference between means 
Table 3. Effect of increasing protein-to-fat ratio (PFR) of cheese milk on the composition of Cheddar cheese ${ }^{1}$

\begin{tabular}{lcccr}
\hline & \multicolumn{3}{c}{ Treatment code $^{2}$} & \\
\cline { 2 - 5 } Cheese composition $^{1}$ & LPFR & MPFR & HPFR & SED $^{3}$ \\
\hline Moisture (\%,wt/wt) & $37.06^{\mathrm{c}}$ & $37.84^{\mathrm{b}}$ & $38.91^{\mathrm{a}}$ & 0.298 \\
Fat (\%, wt/wt) & $34.53^{\mathrm{a}}$ & $31.36^{\mathrm{b}}$ & $28.76^{\mathrm{c}}$ & 0.593 \\
FDM (\%, wt/wt) & $54.86^{\mathrm{a}}$ & $50.44^{\mathrm{b}}$ & $47.07^{\mathrm{c}}$ & 0.793 \\
Protein (\%, wt/wt) & $23.14^{\mathrm{c}}$ & $25.08^{\mathrm{b}}$ & $26.40^{\mathrm{a}}$ & 0.366 \\
MNFS (\%,wt/wt) & $56.63^{\mathrm{a}}$ & $55.12^{\mathrm{b}}$ & $54.61^{\mathrm{b}}$ & 0.373 \\
SM (\%, wt/wt) & $5.15^{\mathrm{a}}$ & $4.89^{\mathrm{ab}}$ & $4.67^{\mathrm{b}}$ & 0.132 \\
Ash (\%, wt/wt) & $3.85^{\mathrm{b}}$ & $3.98^{\mathrm{ab}}$ & $4.02^{\mathrm{a}}$ & 0.066 \\
Ca (\%, wt/wt) & $669^{\mathrm{b}}$ & $737^{\mathrm{a}}$ & $751^{\mathrm{a}}$ & 13.4 \\
Ca (mg/g of protein) & $28.89^{\mathrm{ab}}$ & $29.4^{\mathrm{a}}$ & $28.45^{\mathrm{b}}$ & 0.394 \\
P (\%, wt/wt) & $474^{\mathrm{c}}$ & $514^{\mathrm{b}}$ & $541^{\mathrm{a}}$ & 9.2 \\
P (mg/g of protein) & $20.46^{\mathrm{a}}$ & $20.49^{\mathrm{a}}$ & $20.49^{\mathrm{a}}$ & 0.254 \\
pH at 14 d & $5.28^{\mathrm{a}}$ & $5.27^{\mathrm{a}}$ & $5.23^{\mathrm{a}}$ & 0.028 \\
\hline
\end{tabular}

${ }^{\mathrm{a}-\mathrm{c}}$ Values within a row not sharing a common superscript differ $(P<0.05)$.

${ }^{1} \mathrm{FDM}=$ Fat in DM; SM = salt-in-moisture; MNFS = moisture-in-non-fat substances.

${ }^{2}$ Twenty-three milks with PFR in the range 0.70 to 1.15 were grouped based on PFR as low (LPFR: 0.70 to 0.85 ), medium (MPFR: 0.88 to 1.00), or high (HPFR: 1.01 to 1.15); the number of samples in LPFR, MPFR, and HPFR was 9, 7, and 7, respectively.

${ }^{3} \mathrm{SED}=$ Standard error of difference between means.

absence of significant differences in the MNFS among commercial Cheddar cheeses of different fat contents (Fenelon et al., 2000) attests to such process intervention in the manufacture of reduced-fat cheeses.

The salt-in-moisture content of the LPFR cheese was significantly higher than that of the HPFR cheeses, probably because of a lower moisture content of the LPFR curd at salting, which would be more conducive to the absorption of the salt applied to surfaces of the curd chips during salting and mellowing (Gilles, 1976); at the lower moisture contents, less of the applied salt is lost during salting and pressing. The mean levels of $\mathrm{Ca}$ and $\mathrm{P}$ in the LPFR cheeses were significantly lower than that of the HPFR cheeses, with the MPFR cheese having intermediate values. This trend may reflect the decrease in protein content of the cheese as the PFR decreased. Hence, the ratios of Ca- or P-to-protein (casein) were similar, apart from the HPFR cheese having a significantly lower Ca-to-protein ratio than the MPFR cheese. The lower Ca-to-casein ratio of the HPFR cheese may be due to a greater loss of moisture, and hence, solubilized $\mathrm{Ca}$, during salting and pressing. At the $\mathrm{pH}$ (5.25) of curd at salting, $~ 35 \%$ of the total calcium in Cheddar is soluble (Hassan et al., 2004) and is lost from the cheese to a level determined by the extent of whey loss during salting, mellowing, and pressing.

Although the exact effect of PFR of milk on the grade of Cheddar cheese would have to be established from sensory analysis, inferences can be made on its potential effects based the results of studies showing that the composition of Cheddar has a major influence on quality (O'Connor, 1973a,b, 1974; Gilles and Lawrence, 1973; Fox, 1975; Pearce and Gilles, 1979). These studies have identified 4 key compositional parameters (KCP), namely the levels of salt-in-moisture, MNFS, $\mathrm{pH}$, and FDM, the effects of which are interdependent. Gilles and Lawrence (1973) first suggested the grading of the potential quality of mature cheese based on the ranges of the 4 KCP. Since 1978, this system has formed a basis for establishing the suitability of New Zealand Cheddar for export (Lawrence et al., 2004) and appears to be the only scheme in commercial operation for assessing the quality of Cheddar based on composition. The suggested ranges for salt-in-moisture, MNFS, $\mathrm{FDM}$, and $\mathrm{pH}$ for first-quality Cheddar (Lawrence et al., 2004) are 4.7 to $5.7 \%$ (wt/wt), 52 to $54 \%$ (wt/wt), 52 to $56 \%$ (wt/wt), and 5.1 to 5.3 , respectively; the corresponding ranges for second-grade Cheddar are 4.0 to $6.0 \%$ (wt/wt), 50 to $56 \%$ (wt/wt), 50 to $57 \%$ (wt/wt), and 5.0 to 5.4, respectively (Lawrence et al., 2004). Considering the relationship between cheese quality and the mean levels of the $4 \mathrm{KCP}$, none of the cheese groups in the current study had the desired mean levels of all 4 KCP required for first-grade cheese, and only the MPFR cheese group had the desired mean levels of all $4 \mathrm{KCP}$ for second-grade Cheddar (Figure 3). Closer examination of the data for individual samples indicated that the KCP that deviated most from the target values required for first- or second-grade Cheddar according to the criteria of Lawrence et al. (2004) were FDM and MNFS (Figure 3a). The percentages of all cheeses with values for both FDM and MNFS within the windows for first-grade and second-grade Cheddar were 0 and $13 \%$, respectively, and the corresponding percentages for salt-in-moisture and $\mathrm{pH}$ were 56 and 44\%, respectively. However, the relationship between potential 

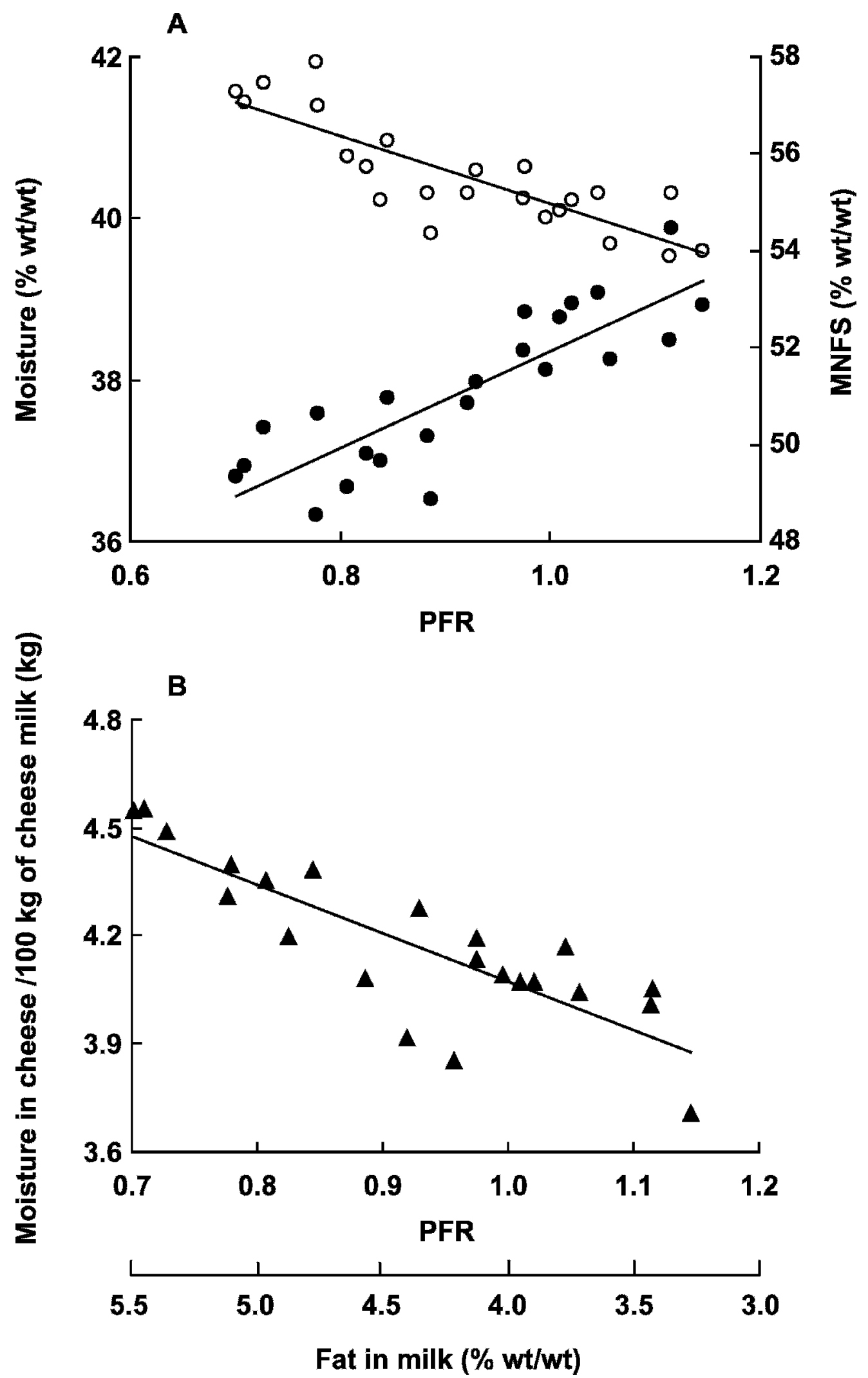

Figure 2. Effect of protein-to-fat ratio (PFR) of milk on (a) the levels of moisture ( ) and moisture-in-nonfat substances $($ MNFS, $\bigcirc)$ in Cheddar cheese and $(\mathrm{b})$ weight $(\mathrm{kg})$ of cheese moisture obtained from $100 \mathrm{~kg}$ of milk $(\mathbf{\Lambda})$. 

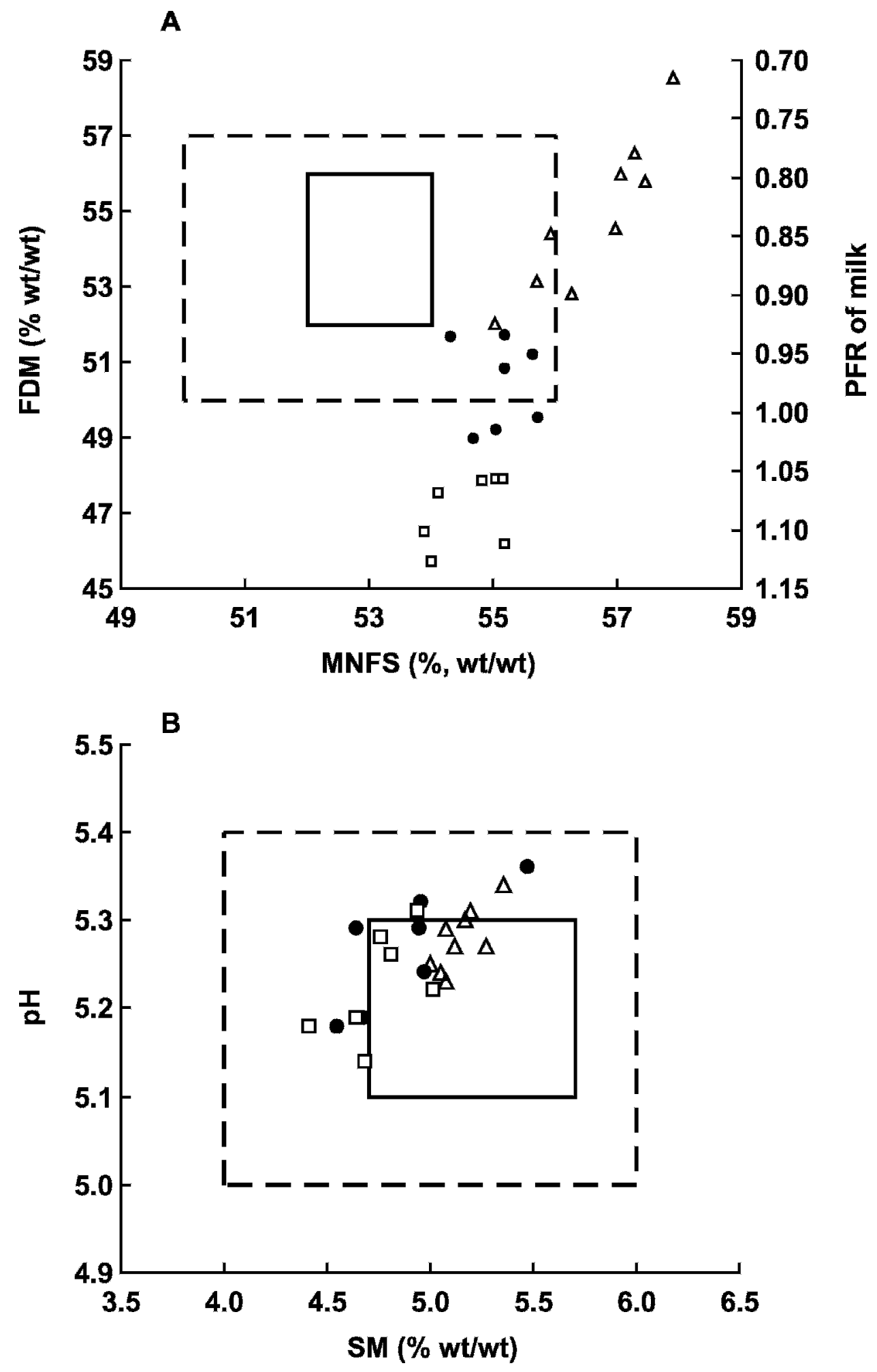

Figure 3. Scatter plot showing the relationship between the levels of (a) moisture-in-nonfat substances (MNFS) and fat-in-matter (FDM), and (b) salt-in-moisture (SM) and $\mathrm{pH}$ for Cheddar cheeses made from milks with different protein-to-fat ratios (PFR). Twenty-three milks with PFR in the range of 0.70 to 1.15 were grouped based on PFR as low (LPFR: 0.7 to $0.85, \Delta$ ), medium (MPFR: 0.88 to 1.00 , 9 ), or high (HPFR: 1.01 to 1.15, $\square$ ); the number of samples in LPFR, MPFR, and HPFR are 9, 7, and 7, respectively. The PFR of the cheese milk is indicated on the secondary y-axis, based on a linear relationship with FDM $(\mathrm{R}=-0.97)$. The boxes bounded by the solid $(-)$ and broken (- - - ) lines indicate suggested compositional ranges for first- and second-grade cheeses, respectively, according to Lawrence et al. (2004). 
Table 4. Effect of increasing protein-to-fat ratio (PFR) of cheese milk on the composition of, and losses of fat and protein in, Cheddar cheese wheys

\begin{tabular}{|c|c|c|c|c|}
\hline & \multicolumn{3}{|c|}{ Treatment code ${ }^{1}$} & \multirow[b]{2}{*}{$\mathrm{SED}^{2}$} \\
\hline & LPFR & MPFR & HPFR & \\
\hline \multicolumn{5}{|l|}{ Bulk whey } \\
\hline Weight (kg/100 kg of cheese milk) & $87.14^{\mathrm{c}}$ & $88.24^{\mathrm{b}}$ & $88.80^{\mathrm{a}}$ & 0.190 \\
\hline Fat $(\%$, wt $/ w \mathrm{t})$ & $0.62^{\mathrm{a}}$ & $0.47^{\mathrm{b}}$ & $0.40^{\mathrm{b}}$ & 0.039 \\
\hline Protein $(\%$, wt/wt) & $1.03^{\mathrm{a}}$ & $1.03^{\mathrm{a}}$ & $1.02^{\mathrm{a}}$ & 0.031 \\
\hline Curd fines $(\mathrm{mg} / \mathrm{kg})$ & $251^{\mathrm{a}}$ & $199^{\mathrm{a}}$ & $265^{\mathrm{a}}$ & 46.0 \\
\hline Fat (\% of total milk fat) & $12.07^{\mathrm{a}}$ & $10.70^{\mathrm{b}}$ & $10.44^{\mathrm{b}}$ & 0.520 \\
\hline Protein ( $\%$ of milk protein) & $24.70^{\mathrm{a}}$ & $24.94^{\mathrm{a}}$ & $24.87^{\mathrm{a}}$ & 0.421 \\
\hline \multicolumn{5}{|l|}{ White whey } \\
\hline Weight (kg/100 kg of cheese milk) & $1.47^{\mathrm{a}}$ & $1.38^{\mathrm{a}}$ & $0.92^{\mathrm{b}}$ & 0.16 \\
\hline Fat $(\%, w t / w t)$ & $6.47^{\mathrm{a}}$ & $5.05^{b}$ & $3.95^{\mathrm{c}}$ & 0.448 \\
\hline Protein $(\%, w t / w t)$ & $1.27^{\mathrm{a}}$ & $1.27^{\mathrm{a}}$ & $1.28^{\mathrm{a}}$ & 0.042 \\
\hline Curd fines $(\mathrm{mg} / \mathrm{kg})$ & $1241^{\mathrm{a}}$ & $1161^{\mathrm{a}}$ & $1168^{\mathrm{a}}$ & 138 \\
\hline Fat (\% of milk fat) & $2.03^{\mathrm{a}}$ & $1.83^{\mathrm{a}}$ & $1.08^{\mathrm{b}}$ & 0.278 \\
\hline Protein ( $\%$ of milk protein) & $0.54^{\mathrm{a}}$ & $0.48^{\mathrm{b}}$ & $0.45^{\mathrm{b}}$ & 0.024 \\
\hline \multicolumn{5}{|l|}{ Total whey } \\
\hline Fat ( $\%$ of milk fat) & $14.08^{\mathrm{a}}$ & $12.54^{\mathrm{b}}$ & $11.52^{\mathrm{b}}$ & 0.530 \\
\hline Protein ( $\%$ of milk protein) & $25.21^{\mathrm{a}}$ & $25.42^{\mathrm{a}}$ & $25.22^{\mathrm{a}}$ & 0.395 \\
\hline
\end{tabular}

${ }^{a-c}$ Values within a row not sharing a common superscript differ $(P<0.05)$.

${ }^{1}$ Twenty-three milks with PFR in the range 0.70 to 1.15 were grouped based on PFR as low (LPFR: 0.70 to 0.85 ), medium (MPFR: 0.88 to 1.00), or high (HPFR: 1.01 to 1.15); the number of samples in LPFR, MPFR, and HPFR was 9, 7, and 7, respectively.

${ }^{2} \mathrm{SED}=$ Standard error of difference between means

grade of Cheddar cheeses and the $4 \mathrm{KCP}$ has to be interpreted carefully as other factors (e.g., total Ca level, ratio of soluble Ca to total Ca, lactate levels, populations and types or properties of starter and nonstarter lactic acid bacteria) also affect cheese quality. It is noteworthy that a later New Zealand study (Lelievre and Gilles, 1982) involving a large number of commercial Cheddar cheeses $(\sim 10,000)$ from 6 plants over 2 manufacturing seasons indicated that the precise relationship between grade and composition varied from plant to plant, from one season to another, and in some cases during the season. There is a need to investigate further factors that influence the relationship between the 4 above-mentioned KCP and cheese grade.

\section{Whey Weight and Composition}

The weights and compositions of the cheese wheys are given in Table 4. Increasing the PFR significantly increased the weight of bulk whey but reduced the weight of white whey. The increase in the weight of bulk whey is consistent with the concomitant increase in the level of water (which accounts for $~ 94 \%$ bulk whey weight) in milk as fat content was reduced. The higher weight of white whey for the MPFR and LPFR cheeses compared with the HPFR cheese may reflect a higher level of curd syneresis during salting and mellowing and pressing of the former cheeses, which also have higher levels of MNFS (Table 3). Such a result is consistent with the higher level of fat in the LPFR and MPFR cheese curds and the negative impact of fat content on the syneresis of curd particles in the cheese vat (Dejmek and Walstra, 2004) where most whey is lost.

The fat content $(\%, w t / w t)$ of LPFR bulk whey was significantly higher that that of the MPFR or HPFR wheys (Table 4). Linear regression analysis indicated that the fat level in the bulk whey was negatively correlated with PFR $(\mathrm{R}=-0.86, \mathrm{df}=21)$ and positively correlated with fat content of milk $(R=0.89)$. This trend was expected because a reduction in PFR of milk coincides with an increase in volume fraction of fat in the gel at cutting and stirring, a higher level of fat available for loss from the surfaces of the freshly-cut curd particles, and a lower volume of whey available to disperse the leached fat. Moreover, the dilution of the protein level of the gel matrix as the fat content increases may attenuate the ability of the matrix to retain fat globules, especially during cutting and early stages of stirring because of its more porous open structure. The percentage of total milk fat lost in the bulk whey showed a trend similar to that noted for fat content (Table 4).

The PFR did not significantly affect the levels of protein and curd fines or percentage of total protein lost to bulk whey, trends expected because of the similarity of protein levels, set conditions, and firmness of gel at cut for all rennet-treated milks.

The effects of PFR on the composition of the white whey were similar to those of the bulk whey, except 
Table 5. Effect of increasing protein-to-fat ratio (PFR) of cheese milk on mass balances, component recoveries, and yields for Cheddar cheese ${ }^{1}$

\begin{tabular}{|c|c|c|c|c|}
\hline \multirow[b]{2}{*}{ Item $^{2}$} & \multicolumn{3}{|c|}{ Treatment code ${ }^{3}$} & \multirow[b]{2}{*}{$\mathrm{SED}^{4}$} \\
\hline & LPFR & MPFR & HPFR & \\
\hline \multicolumn{5}{|l|}{ Mass balances } \\
\hline Total weight & $99.97^{\mathrm{a}}$ & $100.08^{\mathrm{a}}$ & $99.75^{\mathrm{a}}$ & 0.190 \\
\hline Fat & $100.25^{\mathrm{a}}$ & $100.24^{\mathrm{a}}$ & $99.81^{\mathrm{a}}$ & 0.47 \\
\hline Protein & $99.35^{\mathrm{a}}$ & $99.38^{\mathrm{a}}$ & $99.87^{\mathrm{a}}$ & 0.62 \\
\hline \multicolumn{5}{|l|}{ Recovery } \\
\hline Fat (\% of milk fat) & $86.53^{\mathrm{b}}$ & $87.70^{\mathrm{a}}$ & $88.29^{\mathrm{a}}$ & 0.44 \\
\hline Protein ( $\%$ of milk protein) & $73.86^{\mathrm{a}}$ & $73.60^{\mathrm{a}}$ & $74.06^{\mathrm{a}}$ & 0.36 \\
\hline Water ( $\mathrm{kg}$ of water in cheese per $100 \mathrm{~kg}$ of milk) & $4.40^{\mathrm{a}}$ & $4.08^{\mathrm{b}}$ & $4.01^{\mathrm{b}}$ & 0.077 \\
\hline \multicolumn{5}{|l|}{ Cheese yields $(\mathrm{kg} / 100 \mathrm{~kg} \text { of milk })^{4}$} \\
\hline Actual yield, $\mathrm{Y}_{\mathrm{A}}$ & $11.73^{\mathrm{a}}$ & $10.78^{\mathrm{b}}$ & $10.33^{\mathrm{b}}$ & 0.24 \\
\hline Normalized yield, $\mathrm{Y}_{\mathrm{AFPRM}}$ & $10.74^{\mathrm{c}}$ & $10.91^{\mathrm{b}}$ & $11.19^{\mathrm{a}}$ & 0.08 \\
\hline Moisture-adjusted yield, $\mathrm{Y}_{\mathrm{MA}}$ & $12.00^{\mathrm{a}}$ & $10.90^{\mathrm{b}}$ & $10.26^{\mathrm{c}}$ & 0.25 \\
\hline Normalized moisture-adjusted yield, $\mathrm{Y}_{\mathrm{MAFPRM}}$ & $10.99^{\mathrm{b}}$ & $11.03^{\mathrm{ab}}$ & $11.12^{\mathrm{a}}$ & 0.05 \\
\hline
\end{tabular}

${ }^{\mathrm{a}-\mathrm{c}}$ Values within a row not sharing a common superscript differ $P<0.05$ ).

${ }^{1}$ Mass balance defined as outputs (bulk whey, white whey, and cheese) as a percentage of inputs (pasteurized milk, starter culture, rennet and salt) for total weight, weight of fat, and weight of protein.

${ }^{2} \mathrm{Y}_{\mathrm{A}}=$ Actual yield (kg/100 kg of milk); $\mathrm{Y}_{\mathrm{AFPRM}}=$ normalized yield in $\mathrm{kg}$ per $100 \mathrm{~kg}$ of milk with reference levels of fat $(3.4 \% \mathrm{wt} / \mathrm{wt})$ plus protein $(3.3 \% \mathrm{wt} / \mathrm{wt}) ; \mathrm{Y}_{\mathrm{MA}}=$ moisture-adjusted (to $38.5 \% \mathrm{wt} / \mathrm{wt}$ ) yield $(\mathrm{kg} / 100$ $\mathrm{kg}$ of milk); $\mathrm{Y}_{\text {MAFPRM }}=$ normalized moisture-adjusted yield in $\mathrm{kg}$ per $100 \mathrm{~kg}$ milk with reference levels of fat $(3.4 \% \mathrm{wt} / \mathrm{wt})$ plus protein $(3.3 \% \mathrm{wt} / \mathrm{wt})$.

${ }^{3}$ Twenty-three milks with PFR in the range 0.70 to 1.15 were grouped based on PFR as low (LPFR: 0.70 to 0.85 ), medium (MPFR: 0.88 to 1.00), or high (HPFR: 1.01 to 1.15); the number of samples in LPFR, MPFR, and HPFR was 9, 7, and 7, respectively.

${ }^{4} \mathrm{SED}=$ Standard error of difference between means.

that the fat level of the MPFR whey was significantly higher than that of the HPFR whey.

\section{Mass Balance and Recoveries of Milk Fat and Protein to Cheese}

The mass balances for total weight and weights of fat and protein of inputs (pasteurized milk, starter culture, rennet, and salt) and outputs (bulk whey, white whey, and cheese) were similar in magnitude (99.3 to $100.3 \%$; Table 5) to values previously reported for Cheddar cheese (Fenelon and Guinee, 1999) and were not influenced by PFR of the cheese milk.

The mean values of percentage milk fat recovery (FRC) for all cheeses (Table 5) were within the range of values ( $>3$ to $92 \%$ ) reported elsewhere for commercially made, full-fat Cheddar cheeses (Barbano and Sherbon, 1984; McCarron and Strugnell, 1990; Guinee et al., 2005); the large interstudy variation undoubtedly reflects differences in milk composition, manufacturing conditions, and method of fat measurement.

There was a weak, though significantly positive relationship $(\mathrm{r}=0.8, \mathrm{df}=21)$ between the percentage of FRC and the PFR of the cheese milk (Figure 4), with a mean increase in PFR of $\sim 0.7$ per 0.1 unit increase in PFR. This trend concurs with results of Banks et al. (1981), showing an increase in FRC from 87 to $97 \%$ in model Cheddar cheeses as the PFR of the milk was increased from $\sim 0.75$ to 0.85 . Consistent with the trends noted for fat losses in the total whey, the percentage of milk fat recovered to the LPFR cheeses was significantly lower (by $\sim 1.2$ to $1.8 \%$ on average) than that to the MPFR and HPFR cheeses, for which recoveries did not differ significantly. The lower fat recovery in the LPFR cheeses may be attributed to a dilution effect of the protein matrix at the higher fat levels in the LPFR gel and curd, which attenuates the ability of the protein matrix to retain occluded fat globules during gel cutting and stirring and curd handling.

The percentage protein recovered to cheese was similar for all PFR ( 74\%) and concurs with the trend noted for losses of protein in cheese whey (Table 4).

\section{Cheese Yield and Manufacturing Efficiency}

The mean $\mathrm{Y}_{\mathrm{A}}$ of the LPFR cheese was significantly higher ( 1.0 to $1.4 \mathrm{~kg}$ per $100 \mathrm{~kg}$ of milk) than that of the MPFR or HPFR cheeses (Table 5). The higher yield of LPFR cheese is expected because of the higher fat level in the milk (Fenelon and Guinee, 1999). Thus, linear regression analysis indicated a significant $(P<$ $0.01)$ inverse relationship $(\mathrm{r}=-0.88, \mathrm{df}=21)$ between milk PFR and $\mathrm{Y}_{\mathrm{A}}$, with the latter decreasing by $\sim 0.51$ $\mathrm{kg}$ per $100 \mathrm{~kg}$ of milk for every 0.1 unit increase in PFR in the range investigated (Figure 5a). 


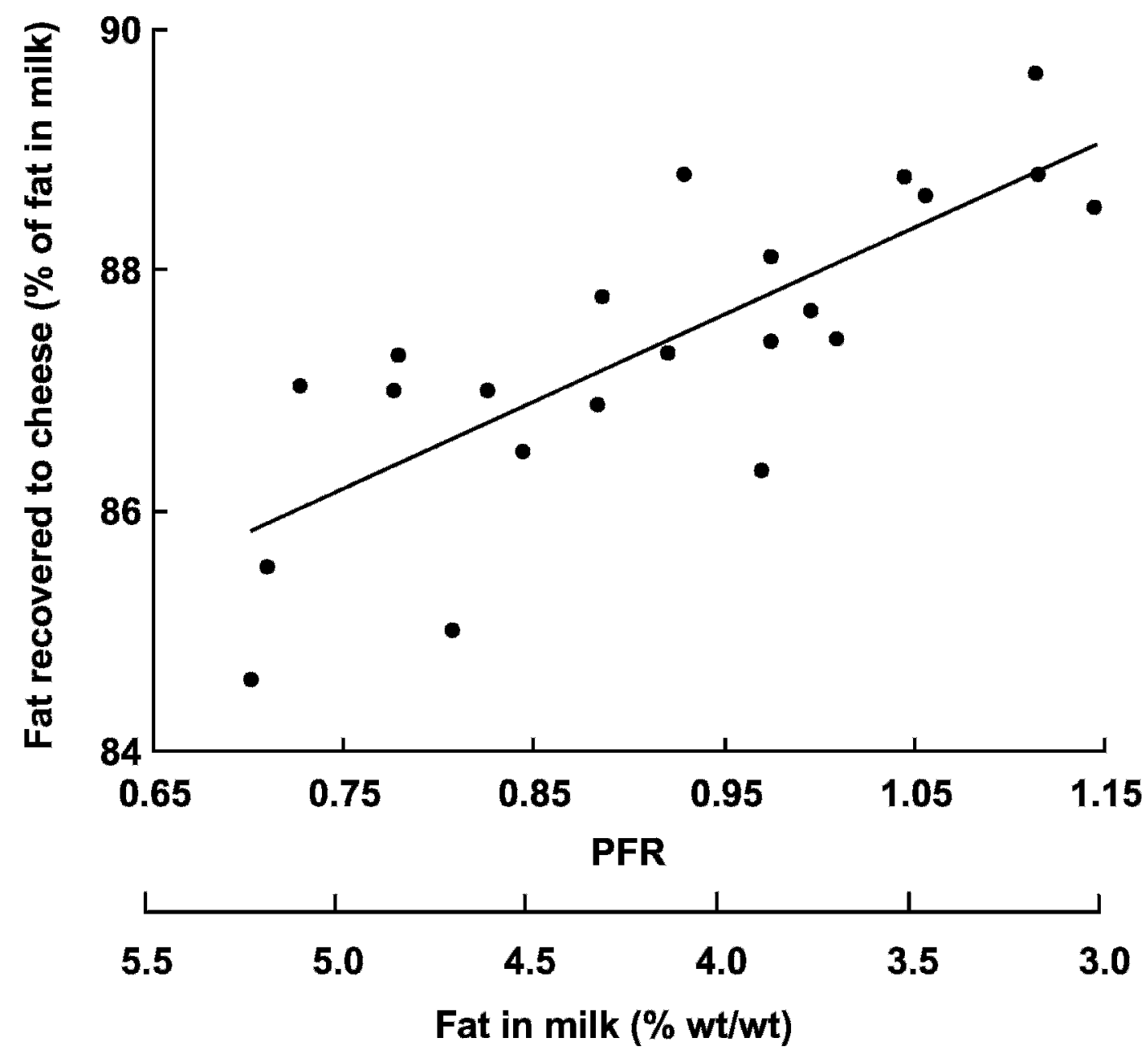

Figure 4. Effect of protein-to-fat ratio (PFR) of milk on the recovery of milk fat to Cheddar cheese.

The mean $\mathrm{Y}_{\mathrm{MA}}(38.5 \% \mathrm{wt} / \mathrm{wt})$ increased in the following order: LPFR $>$ MPFR $>$ HPFR. Similar to $\mathrm{Y}_{\mathrm{A}}$, there was a significant negative correlation between PFR and $\mathrm{Y}_{\mathrm{MA}}(\mathrm{r}=-0.92, \mathrm{df}=21$; Figure 5a). However, the differences between $\mathrm{Y}_{\mathrm{MA}}$ for the LPFR cheese and the MPFR and HPFR cheeses ( 1.1 to $1.74 \mathrm{~kg}$ per $100 \mathrm{~kg}$ of milk) were larger than those for $\mathrm{Y}_{\mathrm{A}}$ because of the positive relationship between the PFR of the milk and cheese moisture (Figure 2a). This effect is consistent with the decreases in MNFS content and WRC as the PFR increased (Figure 2b). Expressing the yield as $\mathrm{Y}_{\mathrm{MA}}$ standardizes cheese moisture to a reference level and thereby facilitates the comparison of the yields of the low-moisture LPFR cheeses with those of the highermoisture MPFR and HPFR cheeses.

To reduce the impact of differences in the fat content of the cheese milks with different PFR, actual yield and moisture-adjusted yields were normalized to $\mathrm{Y}_{\mathrm{AFPRM}}$ and $\mathrm{Y}_{\text {MAPFRM, }}$, respectively, with units in kilograms of cheese per $100 \mathrm{~kg}$ of cheese milk with reference levels of fat $(3.4 \% \mathrm{wt} / \mathrm{wt})$ plus protein $(3.3 \% \mathrm{wt} / \mathrm{wt})$. Opposite to the trends noted for $\mathrm{Y}_{\mathrm{A}}$ and $\mathrm{Y}_{\mathrm{MA}}$, both $\mathrm{Y}_{\mathrm{AFPRM}}$ and $\mathrm{Y}_{\text {MAFPRM }}$ increased significantly with PFR (Figure 5b; $\mathrm{r}=0.81$ and 0.46 , respectively, with $21 \mathrm{df}$ ) and the mean values for the LPFR cheeses were significantly lower than those of the HPFR cheeses. Factors contributing to the increase in $\mathrm{Y}_{\mathrm{AFPRM}}$ as PFR of the milk was raised include the concomitant increases in cheese moisture and recovery of fat from milk to cheese (Table 3, Figure $4 b$ ). Hence, the differences in $Y_{\text {MAFPRM }}$ (which normalizes the moisture content of the different cheeses) among the PFR cheese groups were much smaller than the corresponding differences in $\mathrm{Y}_{\mathrm{AFPRM}}$ (Table 5). Consequently, the r-value for correlation coefficient for the linear regression line between PFR and $\mathrm{Y}_{\text {MAFPRM was }}$ much lower than that of the corresponding regression line between PFR and $\mathrm{Y}_{\mathrm{AFPRM}}$ (Figure $5 \mathrm{~b}$ ). 

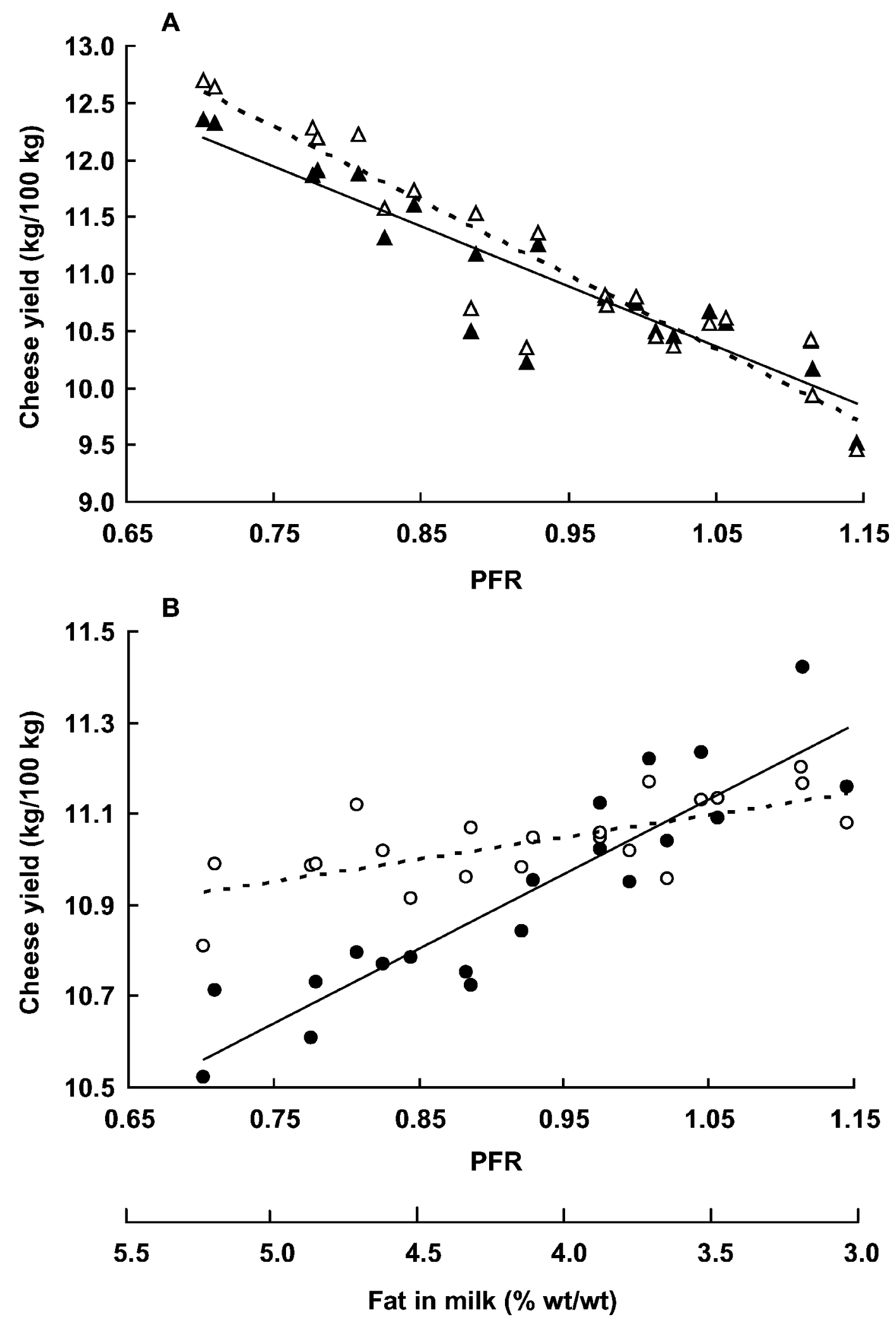

Figure 5. Effect of protein-to-fat ratio (PFR) of milk on yields of Cheddar cheeses: (a) actual $(\boldsymbol{\Lambda},-\longrightarrow)$ and moisture-adjusted (38.5\% wt/ wt; $\Delta$, ----) yields per $100 \mathrm{~kg}$ of milk, and (b) normalized actual $(\bullet,-)$ and normalized moisture-adjusted yield $(\bigcirc,----)$ in $\mathrm{kg}$ per $100 \mathrm{~kg}$ of milk with reference levels of fat $(3.4 \% \mathrm{wt} / \mathrm{wt})$ plus protein $(3.3 \% \mathrm{wt} / \mathrm{wt})$. 
Table 6. Effects of altering the protein-to-fat ratio (PFR) of cheese milk to levels less than 0.8 or greater than 1.0 on Cheddar cheese ${ }^{1}$

\begin{tabular}{lll}
\hline & PFR $<0.8$ & PFR $>1.0$ \\
\hline Advantages & $\begin{array}{l}\text { Higher actual cheese yield } \\
\text { Higher recovery of water from milk to cheese }\end{array}$ & $\begin{array}{l}\text { Higher normalized cheese yield } \\
\text { Higher fat recovery to cheese } \\
\text { Moisture in the nonfat substances (MNFS) approaches levels that } \\
\text { are considered more optimal for good quality cheese } \\
\text { Lisadvantages }\end{array}$ \\
& $\begin{array}{l}\text { Lower normalized cheese yield } \\
\text { Lower recovery of fat from milk to cheese } \\
\text { MNFS increases to levels considered excessive } \\
\text { for good quality cheese }\end{array}$ & $\begin{array}{l}\text { Fat in DM decreases to levels considered to impair cheese quality } \\
\end{array}$ \\
\hline
\end{tabular}

${ }^{1} \mathrm{PFR}$ values of $<0.8$ and $>1.0$ were arbitrarily chosen as extremes as they are outside the range ( 0.8 to 1.0$)$ typically reported for commercial cheese milks.

${ }^{2}$ Actual yield, in $\mathrm{kg}$ per $100 \mathrm{~kg}$ of milk.

${ }^{3}$ Normalized yield, in $\mathrm{kg}$ per $100 \mathrm{~kg}$ of milk with levels of fat plus protein.

Altering the PFR of milk had opposite effects on the different cheese-making efficiency-related parameters: percentage moisture compared with MNFS, recovery of milk fat vs. recovery of water (weight of water in the cheese per $100 \mathrm{~kg}$ of milk) to cheese, and actual yield $\left(\mathrm{Y}_{\mathrm{A}}\right)$ vs. normalized yield $\left(\mathrm{Y}_{\mathrm{AFPRM}}\right)$. The opposite effects of PFR on MNFS and moisture in cheese reflect the depressive effect of milk fat (globules) on the permeability and syneresis of the milk gel on one hand and the dilution effect of fat on the volume fraction of moisture and protein in the cheese on the other. The inverse correlation between MNFS content and PFR coincided with an increase in the recovery of water from milk to cheese. Despite the increase in actual yield and water recovery as the PFR was reduced, the normalized yield decreased owing to the reduction in fat recovery, but the quantity of whey cream (a valuable by-product obtained after clarification and separation of cheese whey) increased. The contrasting effects of altering PFR have different implications depending on the optimization strategy within a particular cheese manufacturing plant; for example, maximizing water recovery, fat recovery, product margin, or all of the above.

Examination of published data from various sources indicated that the natural seasonal variation in PFR of cheese milk typically ranges from $\sim 0.8$ to 1.0 . The current results suggest that this range offers a good compromise between maximizing cheese-making efficiency and obtaining composition that is conducive to acceptable grade and quality. The effects of reducing the PFR of milk to values outside the typical range ( 0.8 to 1.0) found commercially (Figure 1) are summarized in Table 6. The optimum PFR value for a particular Cheddar type (e.g., mild- or mature-flavored) would depend on the optimization strategy used. Factors requiring consideration in targeting an optimum PFR, within the constraints determined by compositional specifications and quality, include milk component recoveries (water and fat), cost factors [milk components, basis of cheese sales (on solids or wet weight), whey cream], and product mix. Having determined an optimum PFR, product margin may be maximized by fine-tuning cheese manufacturing conditions such as type of starter culture or culture adjunct, firmness of gel at cut, cut program, $\mathrm{pH}$ at whey drainage, and type of vat and curd handling technologies.

\section{CONCLUSIONS}

The results clearly demonstrate that alteration of the PFR of cheese milk in the range of 0.70 to 1.15 has marked implications for cheese composition, cheese yield, and the percentage recoveries of milk fat and water to cheese. In particular, the effect of PFR as a lever of controlling the FDM and MNFS content of Cheddar cheese was very notable. These findings highlight the importance of standardizing PFR to within a narrow range to avoid extremes of composition, poor quality, and noncompliance to compositional specifications for Cheddar. On the other hand, the extremes of composition at low and high PFR, especially when combined with other changes in manufacturing protocol (such as selection of appropriate starter or adjunct cultures and manufacturing conditions), offer potential for the development of new Cheddar-like cheese varieties.

\section{REFERENCES}

Banks, J. M., W. Banks, D. D. Muir, and A. G. Wilson. 1981. Cheese yield: Composition does matter. Dairy Ind. Int. 46:15-22.

Banks, J. M., and A. Y. Tamime. 1987. Seasonal trends in the efficiency of recovery of milk fat and casein in cheese manufacture. J. Soc. Dairy Technol. 40:64-66.

Barbano, D. M., and J. W. Sherbon. 1984. Cheddar cheese yields in New York. J. Dairy Sci. 67:1873-1883.

British Standards Institute. 1976. Methods for chemical analysis of cheese. Determination of $\mathrm{pH}$ value. BS 770: Part 5: 1976. British Standards Institute, London, UK.

Bruhn, J. C., and A. A. Franke. 1991. Raw milk composition and cheese yields in California: 1987 and 1998. J. Dairy Sci. 74:1108-1114. 
Chapman, H. R., and J. Burnett. 1972. Seasonal changes in the physical properties of milk for cheesemaking. Dairy Ind. 37:207-211.

Dejmek, P., and P. Walstra. 2004. The syneresis of rennet-coagulated curd. Pages 71-103 in Cheese Chemistry, Physics and Microbiology, General Aspects. 3rd ed. Vol. 1. P. F. Fox, P. L. H. McSweeney, T. M. Cogan, and T. P. Guinee, ed. Elsevier Academic Press, Amsterdam, the Netherlands.

Fenelon, M. A., and T. P. Guinee. 1999. The effect of milk fat on Cheddar cheese yield and its prediction, using modifications of the Van Slyke cheese yield formula. J. Dairy Sci. 82:2287-2299.

Fenelon, M. A., T. P. Guinee, C. Delahunty, J. Murray, and F. Crowe. 2000. Composition and sensory attributes of retail Cheddar cheeses with different fat contents. J. Food Compost. Anal. 13:13-26.

Fox, P. F. 1975. Influence of cheese composition on quality. Irish J. Agric. Res. 14:33-42.

Gilles, J. 1976. Control of salt in moisture levels in Cheddar cheese. N.Z. J. Dairy Sci. Technol. 11:219-221.

Gilles, J., and R. C. Lawrence. 1973. The assessment of Cheddar cheese quality by compositional analysis. N.Z. J. Dairy Sci. Technol. 8:148-151.

Guinee, T. P., J. Kelly, and D. J. O'Callaghan. 2005. Cheesemaking Efficiency. End of Project Report 2003, DPRC No. 46. Teagasc, Sandymount Avenue, Ballsbridge, Dublin, Ireland.

Guinee, T. P., and B. A. Law. 2002. Role of milk fat in hard and semihard cheeses. Pages 275-331 in Fats in Food Technology. K. K. Rajah, ed. Sheffield Academic Press, Sheffield, UK.

Guinee, T. P., B. T. O'Kennedy, and P. M. Kelly. 2006. Effect of milk protein standardization using different methods on the composition and yields of Cheddar cheese. J. Dairy Sci. 89:468-482.

Hassan, A., M. A. Johnson, and J. A. Lucey. 2004. Changes in the proportions of soluble and insoluble calcium during the ripening of Cheddar cheese. J. Dairy Sci. 87:854-862.

International Dairy Federation. 1964. Determination of casein content of milk. Standard 29. International Dairy Federation, Brussels, Belgium

International Dairy Federation. 1982. Cheese and processed cheesedetermination of the total solids content. Standard 4A. International Dairy Federation, Brussels, Belgium.

International Dairy Federation. 1986. Cheese and processed cheese products-determination of fat content (gravimetric method). Standard 5B. International Dairy Federation, Brussels, Belgium.

International Dairy Federation. 1987. Skimmed milk, whey and buttermilk: Determination of the fat content - Röse-Gottlieb gravimetric method (reference method). Standard 22B. International Dairy Federation, Brussels, Belgium.

International Dairy Federation. 1988. Cheese and processed cheese products-determination of chloride content (potentiometer titration method). Standard 88A. International Dairy Federation, Brussels, Belgium.

International Dairy Federation. 1990. Milk-determination of total phosphorus content (spectrometric method). Standard 42B. International Dairy Federation, Brussels, Belgium.

International Dairy Federation. 1992. Milk and dried milk-determination of calcium content (flame atomic absorption spectrometric method). Standard 154. International Dairy Federation, Brussels, Belgium.

International Dairy Federation. 1996. Milk. Determination of fat content (gravimetric method). Standard 1D. International Dairy Federation, Brussels, Belgium.

International Dairy Federation. 2001. Milk. Determination of nitrogen content-Part 2: Block digestion method (macro method). IDF Standard 20-2. International Dairy Federation, Brussels, Belgium.

Kindstedt, P. S., and F. V. Kosikowski. 1985. Alternative test for phosphorous in cheese. J. Dairy Sci. 68:1859-1864.

Lau, K. Y., D. M. Barbano, and R. R. Rasmussen. 1990. Influence of pasteurization on fat and nitrogen recoveries and Cheddar cheese yield. J. Dairy Sci. 73:561-570.

Lawrence, R. C., J. Gilles, L. K. Creamer, V. L. Crow, H. A. Heap, C. G. Honoré, K. A. Johnston, and P. K. Samal. 2004. Cheddar cheese and related dry-salted cheese varieties. Pages 71-102 in Cheese Chemistry, Physics and Microbiology, Major Cheese Groups. 3rd ed. Vol. 2. P. F. Fox, P. L. H. McSweeney, T. M. Cogan, and T. P. Guinee, ed. Elsevier Academic Press, Amsterdam, the Netherlands.

Lelievre, J., and J. Gilles. 1982. The relationship between the grade (product value) and composition of young commercial Cheddar cheese. N.Z. J. Dairy Sci. Technol. 17:69-75.

McCarron, S. B., and C. J. Strugnell. 1990. An examination of fat recovery in a modern creamery. Irish J. Food Sci. Technol. 14:25-33.

Mehra, R., B. O’Brien, J. F. Connolly, and D. Harrington. 1999. Seasonal variation in the composition of Irish manufacturing and retail milks. 2. Nitrogen fractions. Irish J. Agric. Food Res. 38:65-74.

Mistry, V. V., and J.-L. Maubois. 2004. Application of membrane separation technology to cheese production. Pages 261-285 in Cheese Chemistry, Physics and Microbiology, General Aspects. 3rd ed. Vol. 1. P. F. Fox, P. L. H. McSweeney, T. M. Cogan, and T. P. Guinee, ed. Elsevier Academic Press, Amsterdam, the Netherlands.

O’Brien, B., R. Mehra, J. F. Connolly, and D. Harrington. 1999. Seasonal variation in the composition of Irish manufacturing and retail milks. 1. Chemical composition and renneting properties. Irish J. Agric. Food Res. 38:53-64.

O'Connor, C. B. 1973a. The quality and composition of Cheddar cheese. Effect of various rates of salt addition. Part I. Irish Agric Creamery Rev. 26(10):5-7.

O'Connor, C. B. 1973b. The quality and composition of Cheddar cheese: Effect of various rates of salt addition. Part II. Irish Agric. Creamery Rev. 26(11):19-22.

O'Connor, C. B. 1974. The quality and composition of Cheddar cheese: Effect of various rates of salt addition. Part III. Irish Agric. Creamery Rev. 27(1):11-13.

Phelan, J. A. 1981. Standardization of milk for cheesemaking at factory level. J. Soc. Dairy Technol. 34:152-156.

Pierce, K. N., and J. Gilles. 1979. Composition and grade of Cheddar cheese manufactured over three seasons. N. Z. J. Dairy Sci. Technol. 14:63-71.

SAS Institute. 1995. User's Guide: Statistics. Version 6.12 ed. SAS Institute, Inc., Cary, NC. 